\title{
Developing and Teaching Online MBA Courses: Strategies for Enhancing Course Effectiveness
}

\author{
Sunil Ramlall ${ }^{1, *} \&$ Dhanmati Padma Ramlall ${ }^{2}$ \\ ${ }^{1}$ Management Consultant and Associate Faculty, USA \\ ${ }^{2}$ Accounting Faculty, Century College, Minnesota State, USA \\ *Correspondence: Management Consultant and Associate Faculty, USA. Tel: 1-651-210-2761. E-mail: \\ sramlall001@gmail.com
}

Received: December 29, 2017

Accepted: January 15, 2018 Online Published: January 13, 2018

doi: $10.5430 / \operatorname{mos} . v 5 \mathrm{n} 1 \mathrm{p} 23$

URL: https://doi.org/10.5430/mos.v5n1p23

\begin{abstract}
Reflecting similar global business patterns, employees are continuously pursuing means to set themselves apart from their colleagues, including through education. With the advances in technology, availability of online business programs, marketing of university degrees, and the convenience offered through online education, there has been an explosive growth recently in online education, particularly for business degrees, both at the undergraduate and MBA levels. Overall enrollment in U.S. MBA programs has actually decreased in the past five years but enrollment in the online degrees continues to increase.

Given the growth and emphasis in online MBA programs, there has to be measures of quality assurances and ensuring student success through learning outcomes and ability of students to develop the requisite competencies necessary to excel in organizations. Furthermore, Universities have to be using the relevant technologies, students have to demonstrate behaviors that would enable them to succeed in online programs, and faculties have to adapt teaching strategies. So, what actually fosters success and student satisfaction about MBA programs? This paper examines how online class interactions and quality of instructor online feedback can lead to successfully completing an online MBA course and subsequently the MBA program.
\end{abstract}

Keywords: online learning; mba program effectiveness; sunil ramlall; student satisfaction; mba trends

\section{Introduction}

The demand for Master of Business Administration (MBA) education has increased tremendously over recent years (Ramlall \& Ramlall, 2016). Having an MBA is viewed as a means to prepare and subsequently succeed in a managerial role (Whitaker, New, \& Ireland, 2016).

Even with the high demand, there are students and graduates who leave MBA programs without jobs, or claim programs have not enhanced their learning (Leiber, 2016). Furthermore, Universities are facing lower overall enrollment and even forcing some MBA programs to re-invent themselves (Ramlall \& Ramlall, 2016). Enrollment in U.S. MBA programs is down 11 percent overall since 2009, according to a survey of 265 B-schools by AACSB International, an accrediting group (Leiber, 2016). Nevertheless, online and flexible MBA programs report year-on-year application volume growth (Marketwired, 2015).

As learners seek to pursue their MBAs online and Universities generate revenue through online MBAs, there is a greater need to understand how online discussions between faculty and student can enhance student learning as exemplified through student grades and student satisfaction with learning experience with a course and MBA program. This paper examines how online class interactions and quality of instructor online feedback can lead to successfully completing an online MBA course and subsequently the MBA program.

Online MBA student satisfaction is multifaceted. Endres, Chowdhury, Frye, \& Hurtubis (2009) explained that online MBA students' satisfaction with their faculty, courses, and university is not straightforward. Difficulties are continuing to arise with the proliferation of online MBA courses while lacking proper course management and a lack of attention to the special needs of online students (Bocchi, Eastman, \& Swift, 2004; Mangan). More specifically, 
research on students' satisfaction with regard to MBA course delivery is limited, despite a recent increase in publications on the topic (Arbaugh, 2002, \& Ramlall, 2016). Without a clear understanding of how online discussions enable effective learning and student satisfaction, MBA programs will not be able to fully provide a highest quality learning experience for online students, hence the value of this research.

\section{Literature Review}

Online education is defined as a form of distance education that uses computers and the Internet as the delivery mechanism, with at least $80 \%$ of the course content delivered online (Allen \& Seaman, 2008; Shelton \& Saltsman, 2005). The use of computers to educate arose in the corporate arena during the 1980s as companies used computer-based programs to train new employees (Rudestam \& Schoenholtz-Read, 2002).

Universities and colleges began experimenting in online courses in the early to mid-1990s. However, the rapid growth of online education in traditional nonprofit institutions did not start until 1998 (Arenson, 1998). Online education has not only changed the landscape for distance education, but has greatly impacted higher education as a whole across the globe. We have seen the proliferation of for-profit institutions of higher education, the commercialization of education by traditional non-profit institutions, and a continued increase in the demand for online education (Allen \& Seaman, 2011).

Innovations in Web-based communication technologies, corporate virtual teams, and knowledge management systems continue to revolutionize the workplace (Hochberg, 2006). Similarly, MBA programs across the United States (U.S.) have developed online MBA programs as a means of reaching students who would not otherwise enroll for face to face courses or find it more convenient and efficient to pursue their MBA online. Hochberg (2006) further noted today's working professionals are gravitating in greater numbers towards a blended/hybrid online and onsite distance education delivery model to pursue degrees.

Globalization has created meaningful changes to how business is done. The use of technology, demands from consumers, and the nature of competition have forced organization to create different sources of competitive advantage (Hochberg, 2006). Similarly, "the major driver for the growth of distance education has been the opportunity to teach and learn without the restrictions of time and space. This mirrors the trends in global business - with greater distributed workforces - as globalization allows companies to work virtually and collaborate with employees around the globe" (Hochberg, 2006).

Research on student learning in online education falls into three broad categories: (1) ways in which technology tools can address student learning, (2) similarities and differences in learning outcomes between in-class, online, and blended course formats, and (3) appropriateness of online education for various student types (Whitaker et al., 2016). The research on teaching strategies for online effectiveness falls under all three of these categories.

Technology tools support problem solving by exposing students to alternative perspectives and feedback from other students, which gives students an expanded knowledge base and enables them to evaluate and modify their mental models in a more timely and effective manner (Alavi, 1994). Cooperation and teamwork support learning by extending cognitive triggers beyond the individual student and providing social support and encouragement for individual efforts Technology tools support cooperation and teamwork by facilitating information sharing and support for group processes (Alavi, 1994).

This research addresses the following propositions:

1. Online business students have a perceived optimum level of participation necessary to maximize their engagement?

2. Prevalent practices used by faculty to provide feedback to MBA students create an effective learning environment.

3. Satisfaction level of MBA students is determined, in part, with the nature of feedback received from faculty.

Based on the literature review the following propositions have been determined:

Proposition 1: Online MBA students can effectively synthesize and reflect on weekly activities through three to five substantive posts.

Proposition 2: MBA students who view their faculty as being positive will generally be participate more effectively and ultimately be more satisfied with the course and MBA program. 
Data were be obtained from current MBA students enrolled in at least 10 MBA programs across the U.S. and graduates from these institutions. A stratified sampling method was used to ensure that participants are representing both genders and as many industries, different MBA concentrations, and age groups. MBA Program Director and/or Deans assisted in sharing an electronic survey to their MBA students and alumni.

The Program Directors/Deans forwarded the link with the electronic survey to their respective MBA students and alumni. Participation was completely voluntary.

To ensure some level of stratification, the surveys were distributed to students in different functional areas, such as accounting, finance, marketing, operations, and human resource management. This was achieved by ensuring the respective functional capstone areas are included in the survey. Given that almost all of the students in the respective evening MBA program worked full-time, they served as ideal participants, given their diverse backgrounds, working at different industries, a good balance of males and females, a wide range of ages, and varying lengths of time worked at their respective organizations.

\section{Measures}

An important component of classroom learning is the social and communicative interactions between student and teacher, and student and student (Ni, 2015). A student's ability to ask a question, to share an opinion, or to disagree with a point of view are fundamental learning activities.

Number of Weekly Online Posts. This social presence in online learning is accommodated by the discussion area (Nicholas, 2014). Discussions improve perceived learning, according to a study of 116 students by Wu and Hiltz (2004), in which 57\% thought it increased learning quality. Additionally, the discussions were perceived as motivational as over $78 \%$ thought it was a great opportunity "to share opinions between peers and instructors" (p. 144).

Satisfaction with Feedback from Faculty. The satisfaction with feedback from faculty can be of significance especially if faculty are to challenge students to think more critically and to positively reinforce the types of participation necessary to excel in a course and an MBA program.

The meaning of quality is personal, strongly grounded in the previous experiences and future hopes of each individual student (Rapert, Smith, Velliquette, \& Garretson, 2004). For some, the search for a quality graduate program entails evaluating how challenging the academic environment is. Others place a strong emphasis on team-oriented activities (Ulinski \& O'Callaghan, 2002). Some equate quality with breadth of knowledge, and others seek depth in particular areas of the feedback.

Satisfaction of MBA Students. Delivering a high level of service quality is critically important as a means of generating and maintaining loyal customers. That is, exceptional levels of service quality lead to satisfied customers that may lead to recommendation to other potential customers (Carter, 2009).

\section{Results and Discussion}

Using a population size of 423 of which 387 responded, the following results were tabulated. Given the historical participation rates for such studies, this was a relatively high participation rate.

Number of Weekly Online Posts. Using a Likert scale of 1-5, participants were asked to identify the number of posts they view as adequate to have an effective weekly discussion. The mean score was 4.2 rounded to 4 posts per week. Among the reasons MBA students highlighted were the ability to share a main post and then have adequate discussions providing reflections on the readings, sharing personal examples, identifying best practices, asking questions of other students, and clarifying initial post. Ensuring the posts were substantive was viewed as critical. Substantive discussions meant the information advanced the discussion and provided depth to the discussion.

Discussions improve perceived learning, according to a study of 116 students by Wu and Hiltz (2004), in which 57\% thought it increased learning quality. Additionally, the discussions were perceived as motivational as over $78 \%$ thought it was a great opportunity "to share opinions between peers and instructors" (p. 144). The results from this study support some of the existing literature identifying effective and adequate participation in the discussions to ensure there was adequate engagement from students and feedback from faculty.

Satisfaction with Feedback from Faculty. The satisfaction with feedback from faculty can be of significance especially if faculty are to challenge students to think more critically and to positively reinforce the types of 
participation necessary to excel in a course and an MBA program. Using a Likert scale of $1-5$, participants were asked to identify their satisfaction with their faculty and to identify factors that impacted their satisfaction with their faculty.

MBA students highlighted they expected:

1. Faculty to be visible in the discussions and respond to each student at least once.

2. Feedback on assignments should be done within 3-4 days after assignment was due.

3. Faculty to challenge students thinking and comments in the discussions.

4. Provide individual feedback and not generic comments.

5. Provide qualitative and quantitative feedback.

6. Share personal experiences and examples.

7. Reflect on the literature or at least share a relevant citation from which students can gain deeper insights.

8. Provide weekly announcements on what will be covered for the respective week and highlighting the transition from previous week.

Given the expectations, the participants rated their overall satisfaction with their MBA faculty at 3.8. The range was from 2.6 to 5.0 with 5 being highly satisfied with their MBA faculty.

Satisfaction of MBA Students. Delivering a high level of service quality is critically important as a means of generating and maintaining loyal customers. That is, exceptional levels of service quality lead to satisfied customers that may lead to recommendation to other potential customers (Carter, 2009).

The researchers inquired about the participants (current MBA students and alumni of MBA programs) overall satisfaction with their online courses and what factors they were most satisfied with and areas of dissatisfaction. The highlights of the responses are as follows:

1. Students valued the flexibility of the online option.

2. The ability to have asynchronous courses were of value but identified having a weekly synchronous discussion provided a more personal experience and can ask specific questions and even see their faculty and classmates.

3. Students expected to be challenged and not given an easy A. They wanted to work hard and learn from the experience.

4. Students valued when colleagues shared best practices and the faculty promoted and facilitated such discussions.

5. The learning platform should be easy to navigate and access the pertinent information.

6. Support services such as library, career services, and networking opportunities should be priorities.

7. Faculty should be accessible through e-mail, video-conferencing, and telephone as needed. There should be regular office hours.

\section{Conclusion}

The proliferation of online MBA programs continues. Employers have expressed concerns during this research about the rigor of some online MBA programs. Students have also expressed some reservation about instructional quality. The researchers also spoke with accreditation organizations including AACSB and ACBSP for which both stated their continued priority of ensuring highest quality of these online MBA programs.

While there are many choices for students, the differentiation in online MBA programs center around the ability to have a student-centric experience from the university and engaged faculty members. Relevance of curriculum, rigor, and networking opportunities also determine students' satisfaction. While most universities highlight these factors, the differentiation is the extent to which these become implemented strategies and priorities. In future research, comparing online MBA graduates on the job performance to graduates from traditional MBA programs would be of tremendous value. 


\section{References}

Alavi, M. (1994). Computer-mediated Collaborative Learning: An Empirical Evaluation. Management Information Systems Quarterly, 18, 159-174. https://doi.org/10.2307/249763

Allen, I. E., \& Seaman, J. (2008). Staying the course: Online education in the United States. The Online Learning Consortium. Retrieved from http://www.sloanc.org/publications/survey/pdf/staying\%5Fthe\%5Fcourse.pdf

Arenson, K. (1998, October 7). N.Y.U sees profits in virtual classes. The New York Times. Retrieved from http://www.nytimes.com.postu.idm.oclc.org/1998/10/07/nyregion/nyu-sees-profits-invirtualclasses.html

Callister, R. R., \& Love, M. S. (2016). A Comparison of Learning Outcomes in Skills-Based Courses: Online Versus Face-To-Face Formats. Decision Sciences Journal of Innovative Education, 14(2), 243-256. https://doi.org/10.1111/dsji.12093

Gruber, T., Fuß, S., Voss, R., \& Gläser-Zikuda, M. (2010). Examining student satisfaction with higher education services: Using a new measurement tool. International Journal of Public Sector Management, 23(2), 105-123. https://doi.org/10.1108/09513551011022474

Herman, T., \& Banister, S. (2007). Face-to-face versus online coursework: A comparison of costs and learning outcomes. Contemporary Issues in Technology Education, 7(4), 318- 326.

Hochberg, J. M. (2006). Online Distance Education Pedagogy: Emulating the practice of global business, Editorial. Distance Education, 27(1), 129-133. https://doi.org/10.1080/01587910600654841

Koory, M. A. (2003). Differences in learning outcomes for the online and F2F versions of "An introduction to Shakespeare". Journal for Asynchronous Learning Networks, 7(2), 18-39.

Lee, H. J., \& Rha, I. (2009). Influence of structure and interaction on student achievement and satisfaction in web-based distance learning. Educational Technology \& Society, 12(4), 372-382.

Leiber, N. (2016). The Selling of the American MBA. Bloomberg Businessweek, (4468), 52-52.

Marketwired. (2015). Majority of Full-Time MBA Programs Worldwide Report Increases in Application Volume: Marketwire, Incorporated.

Means, B., Toyama, Y., Murphy, R. O. B. E. R. T., \& Baki, M. (2013). The effectiveness of online and blended learning: A meta-analysis of the empirical literature. Teachers College Record, 115(3), 1-47.

Ni, A. Y. (2015). Comparing the Effectiveness of Classroom and Online Learning: Teaching Research Methods. Journal of Public Affairs Education, 19(2), 199-215.

Ramlall, S., \& Ramlall, D. (2016). An Effective MBA: Perspectives of Students, Faculty, and Employers. Journal of Management and Strategy, 7(3), 18-22. https://doi.org/10.5430/jms.v7n3p18

Rudestam, K. E., \& Schoenholtz-Read, J. (2002). Overview: The coming of age of adult online education. In K. Rudestam \& J. Schoenholtz-Read (Eds.), Handbook of online learning: Innovations in higher education and corporate training (pp. 3-8). London, UK: Sage Publications.

Tallent-Runnels, K., Lan, W., Cooper, S., Ahern, C., Shaw, M., \& Liu, X. (2006). Teaching courses online: A review of the research. Review of Educational Research, 76(1), 93-135. https://doi.org/10.3102/00346543076001093

Whitaker, J., New, J. R., \& Ireland, R. D. (2016). MOOCs and the Online Delivery of Business Education What's new? What's not? What now? Academy of Management Learning \& Education, 15(2), 345-365. https://doi.org/10.5465/amle.2013.0021 